\title{
Use of Construction Project Scheduling Methods in the Czech Republic
}

\author{
Nováková Jana ${ }^{1}$, Nový Martin ${ }^{1}$ \\ ${ }^{1}$ Brno University of Technology, Faculty of Civil Engineering, Institute of Structural \\ Economics and Management, Veveř́ 331/95, 60200 Brno, Czech Republic \\ novakova.j@fce.vutbr.cz
}

\begin{abstract}
This article deals with research in the field of construction project scheduling in the Czech Republic. The aim of the research was to determine the scheduling maturity within project management in selected medium-sized and large companies and the change in the use of these methods during the global COVID-19 virus pandemic. The research presented in this article consists of three consecutive steps: determining the research area and the research question, designing a research plan, conducting data collection and analysis and compiling research results. For the purposes of this research, the research question was defined as follows: How do the project management scheduling methods differ depending on the company size in the selected companies in the Czech Republic? For understanding both the context and the situation in the surveyed companies, qualitative approaches to data collection and analysis were used, particularly in-depth interviews and encoding method. This approach was chosen mainly due to the fact that in case of quantitative research, the results tend to be improved by the respondents or irrelevant respondents are questioned. The semi-structured interview questions which were created based on the findings of the current state of scientific knowledge and literary research were used for the needs of in-depth interviews. Open questions (topics) related to the respondents' experience, perceptions and opinions were created as a part of the preparation process. The aim was to get more reliable and relevant answers to the questions asked. The research, which lasted for 6 months, involved 10 medium-sized and large companies from the Czech Republic. The change in the use of scheduling methods took place mainly in medium-sized companies. Large companies emphasized scheduling even before the pandemic, medium-sized companies often neglected this area - planning was not documented, linked to other projects, suppliers or customers. The pandemic has changed this situation. Companies that participated in this research have started to understand integrated scheduling approaches and are going to invest or consider to invest in complex software solutions in the near future.
\end{abstract}

\section{Introduction}

Since ancient times, mankind has been implementing projects without realizing that they really do so. The most famous projects across the centuries include, for example, the Egyptian pyramids, temples of ancient Greece, medieval castles, war campaigns, steam engines or planes. Over time, the profession, currently called project manager, has been evolving and increasingly specifying to its current content. Throughout the centuries, project manager's position, knowledge and skills have been and still are very important, and the success of the project has been and still is based on his/her work. [1] 
Construction project management is closely linked to each construction process implementation. It represents a benefit within all project stages - planning and preparation, implementation, analysis and subsequent risk management, project evaluation and check of achieved goals from the point of view both of the client and the contractor. In the current highly competitive environment, the position of a project manager in a company is particularly important; projects in all their phases are affected by a number of factors that influence its success. The project manager's role is to bring the project to a successful finish using various project management tools, including the use of scheduling methods.

\section{Current approaches to scheduling}

The chapter focuses on the evaluation of the current state of knowledge in the field of construction project scheduling. The analysis of the current state was also supplemented by references to scientific literature that deals with this issue. The best-known scheduling methods include Gantt Chart, CPM, PERT, MPM, GERT, ADM, PDM and CCPM. General methodologies and standards in project management that integrate scheduling, such as PRINCE2, PMI and IPMA also form an inseparable part of scheduling.

The schedule of the project steps forms an integral part of the project plan and contains all the information on the dates and time sequences in which the project work takes place. Implementation resources which perform services according to the assignments of these sub-sections and which are responsible for the task fulfilment and the implementation of outputs associated with a specific assignment of a sub-task, were assigned to individual sections of the schedule. Charts and schedules play an important role in project management methodologies as a tool for complete and clear record of a large amount of information needed for project management. [2] [3]

Detailed and realistic planning is required for project management and monitoring. The Gantt Chart enables to monitor the continuity of individual project parts as well as the degree of fulfilment of the given tasks and the overall time required. The Gantt Chart therefore serves as a visual overview of the monitored process course. This is a kind of bar chart. These charts are widely used nowadays - they are simple, they can be easily created even without specialized software support and no special qualifications are needed to understand them. Specialized applications (GanttProject, SmartDraw, etc.), project management applications (Microsoft Visio, OmniPlan, Microsoft Project, etc.) can be used for their creation, however, a simple version of this chart can even be created using Microsoft Excel. [4]

One of the most important network diagrams, which is used to plan the individual project activity sequences, is compiled by the CPM (Critical Path Method). It serves as a project management tool. This method was developed in the 1950s. It is based on the search and analysis of the so-called project critical path - the longest sequence of project tasks that do not contain any time reserves; the method does not contain combined estimates of the project section duration. [5]

The PERT (Program Evaluation and Review Technique) method represents a standard method of network analysis. In fact it is a generalization of the CPM Critical path method. It is used to estimate the project duration and to determine the minimum time to complete the entire project. It is used in project management and the logistics and transport field. First publication and a detailed description of this method is dated to 1958. Unlike CPM, duration is understood as a random variable that has a certain probability distribution. Three estimates are made - optimistic, pessimistic and the most likely. Subsequently, the weighted duration and standard deviation are calculated. It is a more accurate, however, a slightly more complicated method. [6]

The MPM (Metra Potential Method) method deals with the project time analysis and assumes a deterministic evaluation and network structure. It is an interesting alternative to the CPM method. 
This method assumes a fixed chart origin, stationarity (independence from timeline location) and continuity of all activities. The binding potential is also added to the relational bonds. The main advantage of the MPM method is that it can use the time intervals between activities. However, this method is currently in decline. [7]

The Arrow Diagram Method (ADM) is a method of a diagram representation in the form of network charts, where the activities are represented by the arrows between diagram points. The Network Diagrams method with advanced Precedence Diagram Method (PDM) incorporate the capabilities of previous methods and extend the concept of activity-to-activity links. [5]

Other stochastic methods include GERT (Graphical Evaluation and Review Technique). This is a procedure in which the researched system is described using a graphical approach. It uses the socalled generalized network graph. The GERT method was developed in 1966. [8]

The Critical Chain Project Management (CCPM) method deals with the ways of the best production planning. This method was introduced in 1997. At that time, it was the first significant benefit for project management in the past 30 years. This was the first truly new project management method since the invention of the CPM method. On the one hand, the method significantly shortens project times, on the other hand, it significantly increases the probability of completing all projects on time, without limiting the original specifications and keeping the budget. The critical chain can do this both in the case of individual projects and in a multi-project environment. [9]

\section{Methods used}

Qualitative approaches to data collection and evaluation, especially in-depth interviews and the coding method, were used for contextual understanding and insight into the surveyed companies' situation. The aim was to get more reliable and relevant answers to the questions asked.

A qualitative approach represents a number of different procedures that try to understand the researched issue. The aim is to view a certain phenomenon in the most complex form possible, including relationships to other aspects. It is possible to modify or supplement questions during the research using the qualitative method. The most common techniques of a qualitative approach include in-depth interviews, non-standardized observation and content analysis. In-depth interviews try to capture the deeper causes of certain opinions or behaviour. The interviewer encourages the respondent to formulate his answers by using clearly formed questions. These are subsequently processed and evaluated by the interviewer. The standardized interview looks like reading a questionnaire to the respondent, who choses pre-selected variants of answers. The in-depth interview resembles a free interview, which structure is not fixed. [10] [11]

A semi-structured interview for identifying the time management maturity within the project management in selected medium-sized and large companies and the change in these methods use during the global COVID-19 virus pandemic was used in this research. The structure was compiled on the basis of the current state of scientific knowledge and the scientific literature research. Although the structure was followed, neither the order nor the exact wording of the questions, mattered. The interviewer could adapt them.

The methods of sorting and evaluating data in qualitative research are quite diverse. The coding method was used in this research. Coding is defined as the division of data sets into sub-units segments and their subsequent naming and sorting. This is repeated and refined several times during the analysis. If the material evaluation and its further collection do not bring anything new, theoretical saturation can be achieved and the research can be terminated. Open coding takes place during the first data analyses, it creates categories and identifies basic areas. [10] [12] [13] 
The open coding method was used in this research to process data and evaluate the results of indepth interviews. Open coding, aimed at careful data study, was used in the analysis of in-depth interviews. Categories were compiled and relationships between them were defined based on the codes. Subsequently, the analysed data was rearranged in order to create logical connections between the categories. This coding identified elements that form the issue context of scheduling identification project management maturity in selected medium-sized and large companies in the Czech Republic and a change in these methods use during the global COVID-19 virus pandemic.

\section{Results and discussions}

The research presented in this article consisted of three consecutive steps: determining the research area and the research question, creating a research plan draft, carrying out the data collection and analysis, and compiling a research report.

\subsection{Determining the research area and the research question}

The research question represents the basic starting point of scientific work. In accordance with the research area focusing on scheduling methods, the research problem constitutes the scheduling maturity within project management. The purpose of the research was to assess the change in these methods use during the global COVID-19 virus pandemic and to compare the results between the researched companies. For the purposes of this research, the research question was defined as follows: How do the project management scheduling methods differ depending on the company size in the selected companies in the Czech Republic? Chapter 4.3 deals with the evaluation of the research goal and the research question.

\subsection{Research plan design, data collection and its analysis}

Qualitative approaches to data collection and evaluation, especially in-depth interviews and the coding method, were used for understanding both the context and the situation in the surveyed companies. This was decided mainly due to the fact that in the quantitative research (especially in the case of questionnaire surveys) the results tend to be improved by the respondents or the respondents are irrelevant. A semi-structured interview compiled on the basis of conclusions from the current state of scientific knowledge and scientific literature research was used for the needs of in-depth interviews. 10 open questions (topics) related to the respondents' experience, perceptions and opinions were created during the preparation process.

Table 1. Semi-structured questions used in in-depth interviews

\begin{tabular}{ll}
\hline Index & Question \\
\hline Q1 & What is your role in project management and construction order planning? \\
Q2 & In your opinion, what areas are important for project scheduling? \\
Q3 & What are the biggest shortcomings in project planning? \\
Q4 & What methods, tools and software do you use for scheduling? \\
Q5 & How and by whom is scheduling managed? \\
Q6 & What internal and external factors affect project scheduling? \\
Q7 & What differences in scheduling did you encounter? \\
Q8 & What documents or background materials need to be analysed to create a schedule? \\
Q9 & Does your organization have a project department and a unified management \\
Q10 & methodology? \\
& How did the company's approach to scheduling change during the COVID-19 \\
\hline
\end{tabular}


The group of respondents was defined as respondents who are actively involved in project management and scheduling in medium-sized and large companies in the Czech Republic. Interview were conducted with a total of 23 experts from practice in a total of 10 companies ( 5 medium-sized and 5 large) in accordance with this rule. There was no need to carry out more interviews, since the same data, including identical experience, was repeated in the outputs.

All outputs from the in-depth interviews were analysed, sorted and categorized during this research phase. First, the outputs related to the scheduling maturity within the project management were subjected to a detailed analysis. It was a large amount of unstructured material, which had to be further processed. For this reason, the open coding method was chosen for data processing. Topics were sought in the obtained outputs in order to identify the used scheduling methods and changes in processes during the COVID-19 pandemic. An index that described the classification into a category was assigned to each meaning unit. The process was repeated in several iterations. Five main categories were defined in the open coding process.

Table 2. Research evaluation using the coding method

\begin{tabular}{cc}
\hline Category & Code \\
\hline $\begin{array}{c}\text { Scheduling } \\
\text { methods }\end{array}$ & Project scheduling, network analysis, Gantt Chart, CPM, PERT, \\
MPM., GERT, CCPM
\end{tabular}

\subsection{Compilation of research results}

The aim was to get more reliable and more relevant answers to the questions asked. The research, which lasted for 6 months, involved 10 medium-sized and large companies from the Czech Republic. A typical respondent can be characterized as follows: he has been involved in more than 10 projects, has been in project management for more than 4 years and works as a project manager in companies with a predominant subject of activity as shown in Figure 1.
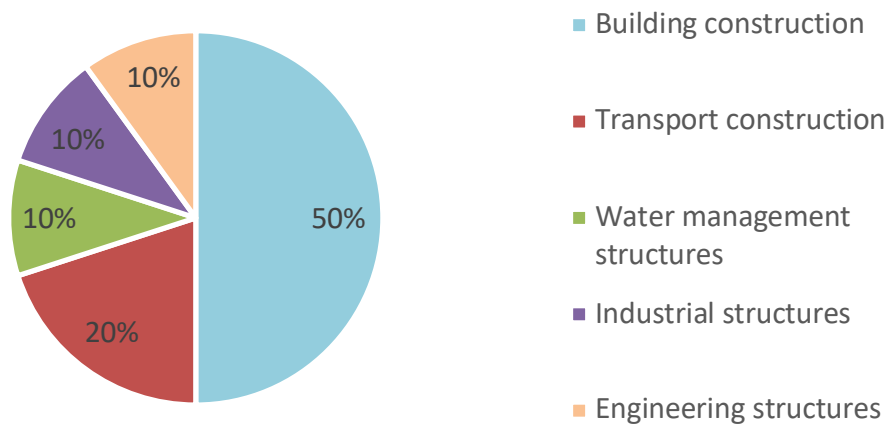

Figure 1. Predominant subject of company activity 
All large companies involved in research had a project department. The situation is different for medium-sized companies, only 1 company had a project department. $60 \%$ of organizations use a uniform project management methodology. There is a significant statistical dependence between the mentioned variables. Therefore, if the organization has a project department, there is a high probability of a uniform methodology use for project management. An overview of project management methodologies is summarized in Figure 2.

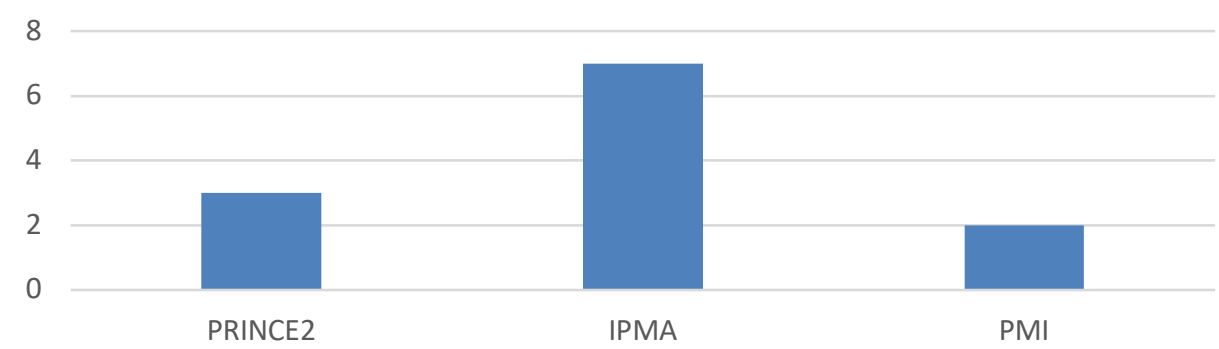

Figure 2. Project management methodologies and standards

The evaluation also examined the impact of the uniform methodology use of project management on the evaluation of impacts and benefits after the completion of project implementation. $70 \%$ of those who use a uniform methodology in project management also evaluate their impacts and benefits, $30 \%$ of respondents do not evaluate the impacts and benefits. Project managers who hold some international certificate (e.g. PRICE2 or IPMA) use the recommended tools more often than noncertified ones. A question about schedules processing was also part of the research. The results can be seen in Figure 3.

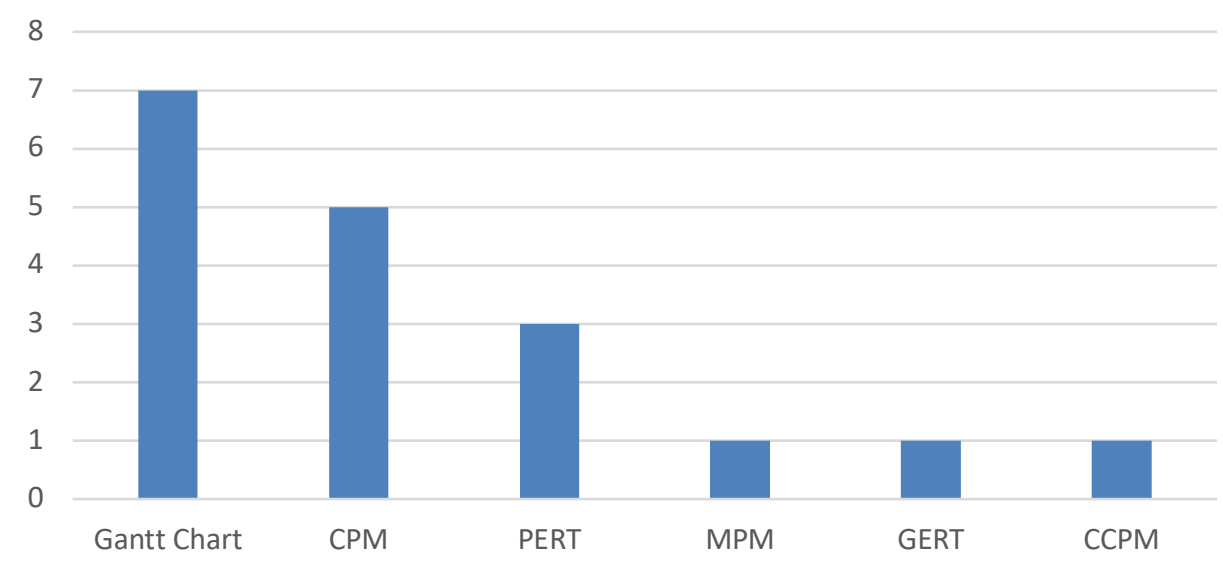

Figure 3. Scheduling methods

The following chart (Figure 4) shows that the most often used tool for construction management is the Excel spreadsheet processor from Microsoft. An easy accessibility and its good knowledge on the part of users is its advantage. Furthermore, the Microsoft Project, which is suitable for scheduling is widely used. Each company typically uses multiple planning tools. Their choice depends on the company size, the project character, but also the user's experience. 


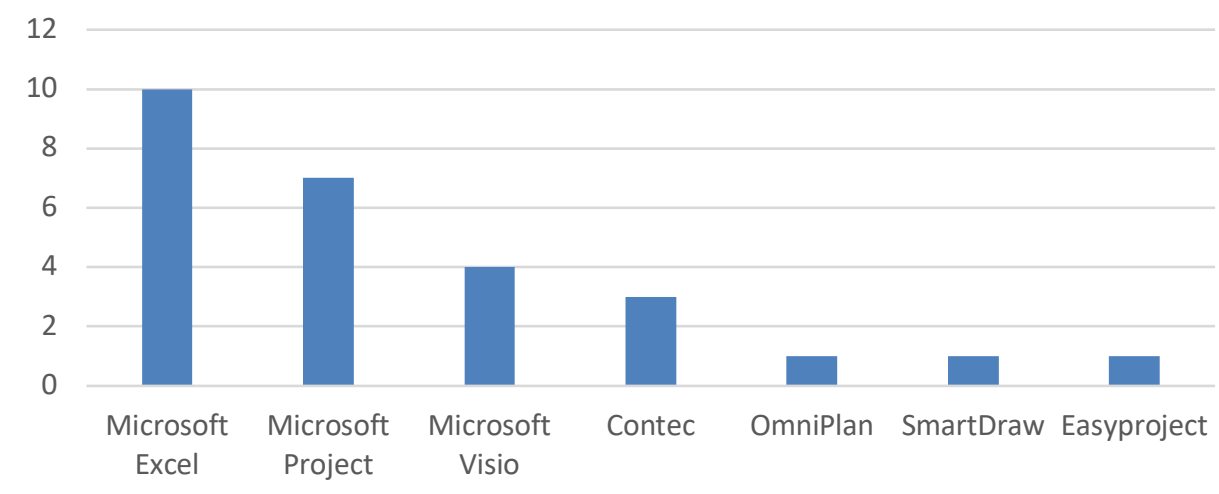

Figure 4. Software scheduling processing

Almost half of the respondents (48\%) stated an ambiguous assignment as one of the most significant scheduling problems. Another large group of problematic factors are relationships with key stakeholders $(78 \%)$, such as delayed deliveries by subcontractors, non-compliance or error in project documentation and failure to obtain the necessary documents and permits in time. Other adverse effects with an impact on the schedule include failure of machinery and production equipment $(22 \%)$, adverse externalities and natural conditions (26\%), breach to technological processes (35\%), overtime by the customer (43\%) or unregulated changes during project implementation $(57 \%)$.

The survey shows that the problems that threaten the construction project scheduling success in the Czech Republic are related to human resources. These include, in particular, insufficient communication and inappropriate construction production coordination.

The impact of the COVID-19 pandemic on construction companies planning was manifested mainly in the following areas: lack of employees (illness, quarantine, decline in foreign labour), delayed material delivery, introduction of home office or increased hygiene measures (mandatory temperature measurement, testing, preventing more workers working together). All the abovementioned factors significantly affected the project time intensity and thus extend the deadlines.

\section{Conclusions}

A large number of companies which manage their business activities through projects can be identified among Czech companies. Project management is not a privilege of large companies, as evidenced by the results of our qualitative research focused on medium-sized and large companies operating in the construction industry. Medium-sized companies deal with projects in the same way as large companies, differing mainly in the number of projects implemented per year and the project management style itself. The biggest differences between medium-sized and large companies can be found in project management.

While medium-sized companies rely more on operational project management, larger companies focus more on the project planning process. This fact also stems from the qualification of a project manager, which is understood as a certification of the manager's expertise, higher education with a focus on projects or their combinations for the purposes of the research. The importance of both the planning process and project risk analysis has been growing with the growing expertise of the project managers in the companies.

The aim of the research was to determine the project management scheduling maturity in selected medium-sized and large construction companies and the change in the use of these methods during the global COVID-19 virus pandemic. Qualitative approach to data collection and evaluation, especially 
in-depth interviews and the coding method, were used for understanding both the context and the situation in the surveyed companies. The research, which lasted 6 months, involved 10 medium-sized and large companies from the Czech Republic. The main topics of the interview were the respondents' project management experience and the use of project management tools and methods.

A change in the use of scheduling methods has recently taken place especially in medium-sized companies. Large companies emphasized time planning even before the pandemic, medium-sized companies often neglected this area - planning was not documented and linked to other projects, suppliers or customers. The pandemic has changed this situation, and companies involved in this research have started to understand integrated scheduling approaches and are going to invest or consider investing in comprehensive software solutions in the close future.

\section{References}

[1] Nový, Martin; Nováková, Jana; Waldhans, Miloš. BV008 Projektové řízení staveb I. Modul 01. Studijní opora. Brno, 2006. Brno University of Technology, Faculty of Civil engineering. Study aids for study programmes with a combined form of study.

[2] Doležal, Jan, Pavel Máchal, Bronislav Lacko a kol., 2012. Projektový management podle IPMA. Prague: Grada Publishing, 526 pp. ISBN 978-80-247-4275-5.

[3] Levy, Sidney M. Project management in construction. 6th ed. New York: McGraw-Hill, c2012. ISBN 978-0-07-175310-4.

[4] JežkovÁ, Zuzana. Projektové řízení: jak zvládnout projekty. Kuřim: Academic centre of students‘ activities, 2013. ISBN 978-80-905297-1-7.

[5] Svozilová, Alena. Projektový management: systémový př́istup k řízení projektů. 3., amended and extended ed. Prague: Grada Publishing, 2016. Expert (Grada). ISBN 978-80-271-00750 .

[6] Doležal, Jan. Projektový management: komplexně, prakticky a podle světových standardů. Prague: Grada Publishing, 2016. Expert (Grada). ISBN 978-80-247-5620-2.

[7] Historie metody MPM [online]. [cit. 2020-3-25]. Retrieved from: http://www.fce.vutbr.cz/veda/JUNIORSTAV2007/pdf/Sekce_5/Vaverka_Miroslav_C L_(1).pdf

[8] Metoda GERT [online]. [cit. 2020-3-25]. Retrieved from: http://etext.czu.cz/php/skripta/kapitola.php?titul_key=77\&idkapitola=69

[9] Historie metody CCPM [online]. 2012 [cit. 2012-04-08]. Retrieved from: http://etext.czu.cz/php/skripta/kapitola.php?titul_key=77\&idkapitola=38

[10] Hendl, Jan, 2016. Kvalitativní výzkum: základní teorie, metody a aplikace. 4., amended ed.. Prague: Portál, 440 pp. ISBN 978-80-262-0982-9.

[11] Široký, Jan, 2011. Tvoříme a publikujeme odborné texty. Brno: Computer Press. ISBN 978-80251-3510-5.

[12] Reichel, Jiř́, 2009. Kapitoly metodologie sociálních výzkumů. Prague: Grada. ISBN 978-80247-3006-6.

[13] Strauss, Anselm A Juliet Corbin, 1999. Základy kvalitativního výzkumu: postupy a techniky metody zakotvené teorie. Brno: Sdružení Podané ruce. ISBN 80-858-3460-X. 